\title{
The Belt and Road: Security Dimensions
}

\author{
Kerry Brown ${ }^{1}$
}

Published online: 6 April 2018

(C) Springer-Verlag GmbH Germany, part of Springer Nature 2018

We live in the era of storytelling and of leaders who are storytellers. That has always been the case. Max Weber argued that politicians are divided into sorcerers or warlords. With US President Trump, French President Macron, Russian President Putin, and above all with Chinese President Xi Jinping, we have people who might have access to plenty of assets of hard power, but who, aware of the cataclysmic risk of even appearing to deploy these, try to achieve their means by the magic power of stories.

However, potent Trump's 'Make America Great Again', or the notion of a new Russian imperium under Putin as the new Czar, it is the Chinese tale has had most traction as it ripples across the world. It is now clear that the most globally significant in terms of its long-term impact of all the events that occurred in the latter part of the twentieth century, Reform and Opening up as it was launched by the leadership around Deng Xiaoping from 1978 ranks either at the top or close to it. The results of the big bang of allowing Chinese entrepreneurial energies to be unleashed which started around that time continue to reconfigure the economic universe to this day. It is increasingly also shaping the future. In a few decades, and perhaps only a few years, China will be the dominant global economy. It will, most remarkably of all, have done this under one party enjoying a monopoly on power and practicing hybrid Chinese socialism. The plot could not be thicker.

As Jie Yu states in her contribution to decision-making in this collection, in the last two decades, the era as former Chinese President Jiang Zemin said in 2000 was one of the strategic opportunities for China, there have been four broad announcements about China's role in the world - four iterations of this Chinese reform story and its meaning for the wider world. These have flowed from the country's entry to the World Trade Organization (WTO) in 2001 which unleashed, against most expectations, forces of productivity that saw China quadruple its economy by 2012. That event alone meant that China had a radically different story to tell once it had reached the era of $\mathrm{Xi}$ Jinping. The first of these iterations was the idea of 'peaceful rise for China',

Kerry Brown

kerry.brown@kcl.ac.uk

$1 \quad$ King's College, London, UK 
announced in a series of articles around 2005. The second was 'harmonious society', which sought to introduce a note of reassurance and placed the onus on good quality co-operation. By 2013, Xi himself announced the idea of 'new model of major power relations' while in the USA. The Belt and Road Initiative (BRI) was launched soon after, originally as the New Silk Road, then as the One Belt, One Road, and now as the BRI.

These four iterations are different parts of one story. But the simple fact is that this story is moving at a fast pace and thus often needs to change. A fundamental element of this story is about how China's growing economic power is leading it to have influence in a number of other areas, some where it desires this, and others where it is reluctant. In 2005, figures like the then US Deputy Secretary of State Robert Zoellick when addressing the National Committee on US China Relations stated that 'We now need to encourage China to become a responsible stakeholder in the international system'. Since that time, China has edged towards achieving this. Spelling out the BRI has figured as a critical part of that process, along with the language of a 'China Dream' where the rest of the world was involved, which started to appear in leaders' speeches from 2013.

The path of articulating this stakeholder role, despite the urging of the USA a decade ago, has not been an easy one. It was never likely to be. As Beijing academic Wang Hui presciently noted around the end of the first decade of the twenty-first century, the distinctive feature of the USA in post-Second World War period was that while it was a nation-state, it was also a post-modern empire. One could establish this duality by looking at the issue of boundaries:

Does America have boundaries or does it not? It certainly has boundaries, since one has to go through customs when one arrives; yet its frontiers may also be in Turkey, Iraq, Afghanistan, and all along China's periphery. It has frontiers everywhere - in Okinawa, in the Taiwan Strait - and we might even say that there is nowhere in the world that is not a US frontier.

This captures a specific conundrum for China as its economy overtook Japan's in 2010 to become the world's second biggest: how to have influence over issues that it felt it had the strategic right and need to, while not antagonising a US which was often jealous and uneasy about this new, unexpected form of competition in the Asian region and which had such ubiquity. Dai Bingguo, State Councillor, with a remit over foreign affairs in 2009 announced the notion of China having 'core interests' as a way of addressing this:

To ensure the US-China relationship develops forward in a stable, healthy and long-term way, it is very important to mutually understand, respect and support the other side, and defend our own core interests.

He stated that these were 'to maintain its fundamental system and state security; next is state sovereignty and territorial integrity; and third is the continued stable development of the economy and society'. This formulation made clear that the imperative for stability and security within China mandated it having predictability and control over external matters that impacted on it. It also clarified, albeit indirectly, the idea that 
issues like the South and East China Sea and Taiwan were conceptualised as domestic ones. This was the final move in the pre-Xi Jinping era towards a clearer international posture, but one that did not give too much ammunition to subscribers of the China threat notion in the USA who were watching closely for signs of assertiveness on Beijing's part.

BRI is partially an attempt to solve this strategic challenge of how China asserts what it believes to be its legitimate rights over specific issues and claims more strategic space. It seeks to emulate the US model of 'invisible boundaries' — of forms of influence and suasion that liberate it from purely acting behind the physical limits of its own territory. Aware that in terms of hard power, its space is limited because of the clear and continuing superiority of US technology and capacity in terms of naval and military assets, the most natural area to achieve this is in the economic. The BRI therefore has at its heart the mission for China to create a vast zone built on economic commonality, one that is presented as being unlike the US imperium because it is non-normative, nonprescriptive, and based on consent. Partners within this zone will be focussed on achieving 'win-win' outcomes. They will be engaged in the construction of interconnectivity through human capital, finance, infrastructure, and trade. As China domestically is rich in social and economic networks, with the government providing a flexible framework for these to co-exist and co-operate (the 'bird in the cage' model of development, as the metaphor from the early 1980s era of reform put it) so it will seek to create this externally, through enabling and supporting networks linked to it and enjoying mutual benefits from it, in the Asian and wider region.

This is the very broad thrust of the BRI idea that it remains predominantly a story rather than something with strong actuality even now is striking. This is largely because of its deliberately non-prescriptive and institution-light nature. In the years since 2013 when the idea was first announced, up to the major BRI conference in Beijing in May 2017, there have been some attempts from the Xi administration on outlining supportive policy architecture and the right institutional basis. The Action Plan of March 2015 from the State Council of the central government stressed a philosophy of connectivity. The Asia Infrastructure Investment Bank (AIIB) was established around this time too. A small leading group at the central of the Party State apparatus was also set up in Beijing, headed by a then Politburo Standing Committee member, Zhang Gaoli. But these were bare necessities. In promotion of the idea, Chinese leaders around $\mathrm{Xi}$ have been clear that they want an idea the wider world and potential partners can respond to and have some ownership over.

It might be that from 2018, now that the BRI has been formally written into the Party Constitution after the 19th Party Congress in late 2017, Beijing will be seeking more validation. Reports of British Prime Minister Theresa May experiencing problems through disagreeing to formally commend the BRI during her early 2018 visit were an extension of the tensions between the EU and China at the aforementioned May 2017 summit, where the Union also refrained from signing up to a formal trade statement supporting the idea. The BRI sits alongside Xi Jinping through, also put in the constitution, as a core means of achieving the current ideological objective- 'modernisation of socialism with Chinese characteristics for the new era'. As Mao had the 'Five Principles of Peaceful Co-existence' sitting alongside his more muscular approach to neighbours, and Deng had the ' 24 character statement' of biding time and keeping a low profile which allowed concealment of the political aspirations behind China's economic 
strengthening, so the BRI might be critiqued for saying one thing and meaning another. It would hardly be the first time this had happened in Chinese political discourse!

One key aspect that all of the following essays make clear is that while the BRI speaks the language of economic commonality fluently and is predominantly embraced by the formal and less formal partners of the idea as one with economic utility, underlying it are complex issues focussed on security. These are intimately connected to the indigenous and highly specific Chinese contemporary notion of stability. As a country with a long history of internal and external instability, from both natural and human causes, and emerging from a century of great turbulence and upheavals, it is unsurprising that worries about stability weigh heavy on the Chinese leadership's minds. For all their other tasks, Chinese elite Communist Party officials are predominantly risk managers.

It was as a means of addressing risk that the Reform and Opening up was formulated in the way it eventually turned out to be-as a pragmatic means of using Marxism Leninism in its unique Chinese form to build up as the primary stage of socialism a strong economic superstructure. This got entangled with ideas which were more deeply established in the Chinese world view of using foreign ideas for local use and of forging a national form of modernity which finally worked for China after decades of often tragic failure. Economic development has always been a means to an end in the thinking of the Chinese Communist leadership — with the end the creation of a rich, strong, powerful state. The two Xi Jinping Centenary Goals map out this teleological view of the future, with 2021 and the hundredth anniversary of the CPC itself the first step. 2049 will see the completion of this process, culminating when the PRC reaches a hundred years with 'democracy with Chinese characteristics'.

Along this path, questions of how to manage and deal with risks, and how to ensure stability, have been key. In the era after entry to the World Trade Organization in 2001, for all the splendid economic growth, a China growing wealthier by the day was also one aware of the sources of contention through rising inequality and imbalances. The Premier of China under Hu Jintao, Wen Jiabao, referred to the Chinese economy being 'unstable' and 'unsustainable'. But there were also associated sources of instability within Chinese society, leading to estimates of up to 180,000 protests each year by 2011. Yu Jianrong of the Chinese Academy of Social Sciences was to be the highest profile and most detailed chronicler of this emergence of widespread contention in Chinese society.

The policy and administrative response of the Chinese government was to privilege preservation of a specific notion of stability ('wending') within the concept of a 'harmonious society' ('hexie shehui'). All of that elided with the language of 'peaceful rise' and 'peaceful development' and the core Hu Jintao ideological formulation written into the Party Constitutions in 2007 of 'scientific development'. These married notions from ancient Chinese philosophy are taking people as the key, but also stressing collectiveness and social responsibility and seeking of common goals and unity. Stability in this framework occurs as part of a carefully formulated view of the world, one which refers to ancient notions of 'all under heaven' ('tianxia'), or a supporting sense of natural and social hierarchy, mixed in with ideas of order and progress from Chinese style socialism.

All of that language underlines the Chinese contemporary imperative to 'preserve stability'-('weiwen'). The suite of 'weiwen'-associated policies came to the fore under 
$\mathrm{Hu}$ Jintao. Preservation of stability became one of the core responsibilities of provincial leaders. Hard and soft methods were used, ranging from use of paramilitary and even armed force to put down protests, to the deployment of more conciliatory methods as evidenced in the Wukang protests in Guangdong province in 2011, where negotiation was the key management tool. 'Weiwen' was the driver behind large increases in expenditure on domestic security, rising to over 123 USD billion by 2013, more than the figure on national defence (USD 119 billion) which came in at USD 4 billion lower.

Since 1978, after the era of Maoist truculence which saw three significant wars on China's borders (with the UN in North Korea from 1950 to 1952, with India in 1962, and the USSR in 1969), China under reform saw only one clash with a neighbour - that in 1979 with Vietnam. The Deng Xiaoping rubric of development was predicated on enjoying a largely benign, predictable international environment while it sorted its own internal issues out. That approach still continues. China has joined most multilateral entities and has been a highly active partner for the UN, the WTO, and the International Monetary Fund (IMF). It has also, with the Shanghai Cooperation Organisation and the AIIB, set up some of its own entities. In BRICS, the Association of South East Asian Nations (ASEAN), and the Asia Pacific Economic Conference (APEC), and almost everywhere else, we can characterise China as an enthusiastic but maverick multilateralist. This drivers behind this too have been in building security through predictability, in attending to the furtherance of a defence of core interests Dai Bingguo mentioned in 2009 by marrying domestic needs for security with external ones. There is now an explicit link between the global environment in which China sits and its meeting the challenges within itself. Preserving stability and security is critical. This continues under Xi Jinping and lies behind, for instance, his highly proactive foreign travel since becoming president (almost fifty countries since 2013), the statements he made at the start of his time in power to the need for a more proactive stance by China in foreign affairs, and the notion of China now coming close to a moment of core strategic opportunity where it can fulfil its dreams of modernisation on its terms and be restored to a central place in the world.

The BRI domestically was built on this thinking, mixing notions of the utility of a more predictable, benign international environment for China with connectivities that worked for it, and an imperative to promote preservation of security which was built on a specific philosophy of stability. Within this philosophy of stability, there are very different ideas about values, rule of law, and how to view dispute resolution and international order. As the BRI moves from being a mostly abstract, aspirational, notional idea to one with more projects, more example, and more reality, the working out of how these Chinese originated principles sit with those outside is likely to come to the forefront.

It is in this space that the EU will find particular challenges. The EU as a trading partner, and a market, makes very obvious sense to China, simply because of its size. One of the core stories that has been told in the Xi era sitting alongside that of a New Model of Major Power Relations along which to direct the Sino-US relationship and make a bid for parity between the two is that of the European-China relationship being one based on 'civilizational partnership'. That was the term used by Xi when making the first every visit to the headquarters of the Union in 2014. It is a phrase which captures well the synergies and strengths between the two- their pride in their culture, the ways in which they operate as intellectual partners-but it also underlines their 
differences, with China as a unitary nation state and the EU as 28 members at present, and with a number of other countries in the continent which are not in the Union but associate with it and each other closely.

Intellectual partnership between the EU, Europe, and China is amongst the strongest in the world. Without this, it is not likely that the reform process in the PRC would have proceeded as it has done. The Chinese high-speed rail network, standing at a magnificent 24 thousand kilometres as of 2018, is a monument to this - a technology originating in Germany, but which China took and made its own, now developing it even further than originally expected. There are other areas from aviation to healthcare where the two work together. It was probably this aspect of their co-operation that made the failure to lift the arms embargo in 2003 so problematic to China, because in effect, it cut down the scope for even more technological co-operation.

The BRI, as Ramon Pardo's chapter on finance makes clear, offers potentially a lot to Europe. China as a course of capital and investment is attractive and addresses unmet needs within Europe. As he states, 'diversification is key to the financial security of Europe'. And finding such a vast new source of investment is serendipitous, especially in view of the retrenchment of some sources in the USA under the presidency of a more introspective Donald J Trump administration. Even so, questions of values and of cultural dissonance haunt the EU/Europe China relationship, creating an almost dual track approach to the BRI. This dual track works across the geography of the EU in creating sharp divisions and differences within the nation states in how they engage with China. Pardo refers to the most well known of these, the 16 plus One grouping, which was contentious from the start in the ways in which it created a China-focussed grouping of EU and non-EU European states, placing strains on a unified EU posture on economic and political issues with China.

That issue is compounded by a schizophrenia even within nations as they contemplate higher flows of trade and investment from China coming to them. On one level, of course, this new source of financial support is good. Serbia, Poland, and Greece, to name three examples, have shown interest, or received Chinese investment. But in each place, the outcomes have been complex. Plans for BRI-inspired infrastructure building rail links between Belgrade and Bucharest hit EU regulations, causing a candidate nation like Serbia to withdraw. For Greece, the Chinese stakes in Piraeus port and in other areas was suspected to be behind their effective vetoing of a resolution from the EU critical of Chinese human rights issues in June 2017. For Slovenia, the story is more typically one of a small nation interested and keen about Chinese involvement, but also feeling overwhelmed, and not seeing a great deal of action so far. These three cases typify the complexity and the lack of a uniform story that each partner is hearing. These have generic similarities with examples happening closer to China, in the Asian region, where BRI-inspired projects in Indonesia have experienced labour standards issues, or where there have been claims that a large proportion have involved Chinese state companies, Chinese labourers, and benefits accruing to China.

The EU sees itself as the standard bearer of a set of values which are universal and are enshrined in some of its most important documents - notions of rule of law, human rights, and labour standards, broadly gathered under the description 'enlightenment values'. It is clear that that the Xi leadership has set itself against what it calls these externally imposed, disruptive, and often ill-motivated values. Document Number Nine, in early 2013, for instance, was issued from the State Council and offered fierce 
prescriptions against adopting notions characterised as Western. This is not new. Since the Great Financial Crisis of 2008, the Chinese Party State and its elite leadership have been increasingly sceptical of western models which, in the past, were often urged on them. They see the collapse of the USSR and what happened in Russia over the 1990s as a textbook of what the CPC will not do. All of these typified the dreaded instability and lack of security which China most fears. The BRI is a concept that therefore promotes flexibility and tolerance on one level, but which to its critics is a case of China now exporting its philosophy of development beyond its borders - a philosophy which is largely self-interested, lacks legal structure, and supports state development in order to build a strong Chinese state.

This is not to deny that the BRI does have great utility. In the era of the $\mathrm{Hu}$ leadership, the Chinese elite leadership was often silent on what China's international intentions were. Under $\mathrm{Xi}$, there has been much better communication. The BRI is an attempt for China to tell its story to the world. This story needs listening to, because of China's increasingly global importance. And there is nothing wrong in a country of China's status and importance setting out what it feels is its legitimate and justified space and role. It would be strange it if didn't do this. The BRI is therefore a hugely useful piece of information about the shape and contours of China's intentions. It maps out China's ambitions. But it also makes very clear that all of those China is speaking to - and that pretty much means the rest of the world these days - have to think hard about how they respond and what sort of counter-narrative they have to the one China is proposing. This is, after all, a dialogue. And simply passively listening to China's intentions and demands and not taking a proactive stance back would be a mistake.

This is illustrated by the very different regions and sectors that this collection focusses on. These arose from a workshop on the BRI, 'One Belt, One Road: Security Dimensions', held in October 2016 at King's College, London, and convened jointly with the London Asia Pacific Centre for Social Science and the Lau China Institute, both at King's, and the College of Europe, in Bruges. In terms of regions, this meeting confirmed that that of Africa, the Middle East and Central Asia are the most interesting, beyond Asia itself, where China's needs and importance are self-evident. Africa has been an increasingly significant place for Chinese involvement over the last decade. It has a vast area, a big market, and rich resources. All of these attributes matter to China. But it is also offering African states a new partner, one which is not tied to the old colonial style histories such as Europe or the US, and which in that sense comes untainted. China's investments and its aid are largely unburdened with a subliminal message supportive of Western style democratic values. For African nations, China is the ultimate realist player, an entity coming and talking the language, at least on the surface, of straightforward win-win co-operation and mutual benefit. It offers a new source of export markets, of development funding, and capital.

But Africa is a complex terrain, and one that does pose security challenges to China. As it increases its exposure there and starts to acquire assets, its views on the stability of partners and their ability to provide security for its interests increase. The BRI provides a new Africa centred narrative for the emergence of this new potential partner, China, but it sits alongside things that reveal a richer and more complex story. China has been a huge and generous support of peacekeeping forces through the UN. It has worked with African partners to deliver aid projects that address poverty and inequality. In Djibouti on the east coast of the continent, it has a major new naval security facility. 
Just as Robert Zoelick requested in 2005 (see above), China is truly now a stakeholder in this region. But it is one operating in an environment it has little expertise and with partners who are often unstable and unpredictable. All of this shows the reason why China's Africa strategy is dominated by one particular characteristic - cautiousness.

Cautiousness is also in evidence in the links with the Middle East. This is a region where, as Hai Yang in their contribution shows, China has one compelling needenergy. But in order to fulfil that need, it is irrevocably pulled into security issues and the treacherous, intractable internal politics of the region. China has been assiduous is ensuring that it maintains, perhaps uniquely, positive relations with each of the main countries. This includes the Palestinian authorities and the Israeli government. China has major investments in Iran and was a positive partner in the negotiations between the EU, USA, and Russia in order to broker the nuclear freeze deal in 2015. It has been a defender of this deal against the Trump presidency scepticism. In Iraq too, it has started to invest, and in Libya, the extent of its engagement even before 2011 and the antiQaddafi uprising there saw it repatriate over 36,000 nationals - the largest exercise like this it had ever been involved with. As the ongoing civil war with Syria shows, however, the fact that China has supported a series of vetoes (usually alongside Russia) on UN resolutions from 2011 urging action and imposition of sanctions on the Assad government, there are limits to China's willingness to get involved. While the USA, because of the decrease of its energy dependency on the region, has become increasingly disengaged, China stands well placed to fill a vacuum - but also highly aware of the challenges it if does so. All of this is complicated for it by the domestic issues with Islamic extremism and the Xinjiang Autonomous Region, with links to political and financial support from some Middle Eastern partners. Once more, the BRI offers a potential framework for partnership, in a region where, as Hai Yang states, there is "no overarching ... institutional structure for managing and resolving interstate disagreements'. Xi Jinping's tour of the region, from Egypt, to Saudi Arabia, and Iran in early 2016 did see the issuance of the White Paper on the region. But it was a thin document, high in rhetoric and low in detail.

The BRI in Central Asia is a much more present and tangible phenomenon. Here, as Bavna Dave and Yuka Kobayashi argue in their contribution, the question of how much the idea is the result of highly deliberate strategic decisions, and how much is ad hoc becomes central. For Russia, which has been so influential over the region ever since the period when many of the countries which are now independent were part of the USSR, there might be jealous unease. The challenge of creating space and notions of common interest which do not arouse antagonism from another important partner parallel those in the Asia maritime region with the USA. Certainly, BRI investments allow a potentially significant source of new capital and expertise. There are train and road links that could be built which would serve the region and also supply an important new land route for a China aware that it is currently heavily dependent on sea routes for much of its energy and trade. But as Dave and Kobayashi show, debt levels of governments in the Central Asia region in taking out loans from China, however attractive they look, have caused imbalances and financial burdens which are not easily sustainable. Sometimes some things are too good to be true for a reason: they are really too good to be true!

If security plays across the separate regions, the BRI extents to, running beneath the more overt narrative of economic co-operation, one of the principle offers the idea 
presents is of using Chinese prowess as building infrastructure to help with logistics and for the transport in particular not only of goods but of energy. China remains an energy hungry nation, and despite the shift under Xi Jinping and Premier Li Keqiang to the so called 'new normal' where services and consumption as a proportion of the Chinese economy are rising, manufacturing remains important. Chinese state energy companies are key players and stakeholders in BRI. They are in some ways the infantry of Chinese influence, with Petrochina, Sinochem, and Sinopec having operations and personnel in almost every area of the world now. As Kaho Yu argues in their contribution on global energy governance, the construction in the EU of a Trans-European Energy Network (TEE-N) operates as an example of attempting to build a common energy framework across diverse and different partners. As with China, so too is the EU hungry for energy, importing from diverse sources and attempting to find sustainable new sources. And like with China, decent infrastructure is crucial. Linking with the chapter on finance, this one also shows how China is at attractive potential partner, with large amounts of capital, and many areas of common interest.

For the EU, as with many other partners, there is much that the BRI can offer. To borrow Jie Yu's phrase in her chapter on governance and responsibility of BRI within the country, it is an idea that is 'fluid in nature, opaque in implementation plan, and flexible in concrete meaning of projects'. This lack of a meaningful list of achieved projects, because it is such an early phase, is one of the great problems of BRI. The idea is one full of potential, but it is also abstract and sometimes too notional. Jie Yu refers to the ways in which this is true not just in the way that BRI looks to the outside world, but is also reflected in the ownership of the initiative domestically. Not a policy, with a settled architecture of implementation, it is more a space for negotiation and contestation, where provinces and the Centre find a new area to continue their centuries old tussle for influence, and where ministries at the Centre in Beijing are also stakeholders, rather than having any one in particular taking ownership. This has advantages, in creating creative tensions and avoiding bureaucratic inertia. But it also means there is sometimes a lack of focus and, in a system still highly hierarchical, a certain oddness about this notionally democratic 'everyone has a role, everyone has a potential voice' nature.

One issue that BRI does bring to the fore, and where opportunities for EU and other outsider involvement appear, is that of expertise. China's engagement with Africa, Middle East, and, to some extent, Central Asia has been recent. It has little mature expertise in these areas, with Jie Yu estimating that there might be no more than 20 experts on the Middle East and Central Asia in the whole of China. Most of these are figures not networked into the formal government system. So their advice is, despite its clear value, marginalised. The EU, through the length of its engagement historically by some of the main members states, however inglorious a lot of that history might have been, does have hard won language and cultural skills, particularly in the Middle East. It also has more diverse populations in terms of ethnicity, some of which have recent links to the geographies being talked of. Partnership between Chinese entities and these sources of respected external expertise would make sense and, in some cases, has happened. Win-win has often been dismissed as a piece of Chinese government rhetoric. But in this space, of knowledge co-operation and pooling of good quality expertise, the outcomes could genuinely be to everyone's advantage, with China gaining ideas and insights it currently does not have, Europe finding a relatively constructive co-operative role, and the countries and regions being concentrated on at 
least have attention and policies directed at them based on decent empirical evidence and analytic methodology.

BRI is above all things a great learning process. It is also an inevitable one. Short of China obediently staying in its restricted regional box, it is hard to see how such a globalised economic actor (in 2017, chief trading partner to over 120 countries) might maintain the myth of it being an introspective, local actor with no broader aspirations. For all the issues raised in this chapter, and in the rest of the book, China can no longer be accused of being secretive or mute about its vision for its role in the world. It is proactively articulating a vision, and one that at least allows space for others to enter into dialogue with it and shape its ideas just as much as they might be shaped.

BRI will result in the world with more signs of Chinese influence and more knowledge of China. The domestic reforms from 1978 undertaken by the Deng leadership had two central postures. One was to 'cross the river by feeling the stones'. The other was to 'seek truth from facts' (a phrase that originated much earlier in the Maoist period, but came into its own under Deng) and 'make practice the sole criterion of truth'. For all the talk of the Xi era offering a radical departure from the era preceding it, in fact, the Dengist pragmatic parameters remain firmly in place, and $\mathrm{Xi}$ is Dengist in his adherence to them. The clue, after all, is in the longer title of his new ideology, 'modernisation of socialism with Chinese characteristics' where the final four words were the key components of Deng's own ideological innovations post-Mao in the 1980s. This means that the BRI behind the grand rhetoric and fanfare will remain pragmatic, will more likely than not be characterised by cautiousness, and have at its core notions of support for stability and security. Describing it accurately not as people might want it to be, coloured by their aspirations or their reservations about China itself and the political model it currently has, would be a missed opportunity. It is best to see it clearly as it is, in the ways in which it really relates to how people engage with Chinese investment, speak about security issues with China, and employ the new kinds of connectivity in terms of ideas, people to people links, capital, and, most important of all, values. China managed to embrace a raft of ideas from the capitalist west post 1978, without, in the end, changing its notion of being strongly Chinese. Its identity as Chinese is as strong now as ever-perhaps even stronger. For the outside world, the rise of worries about Chinese newfound influence and the ways this might change them need to be set against this prior example of China. They need to see positive ways in which a dialogue with China can be a proper two-way street, without the idea of threat or negative disruption. In that sense, the BRI is finally about the construction of an epistemic community, one literate and comfortable in talking about and thinking about China. That may well prove to the most enriching thing about this whole idea and the place where it may make its most enduring and sustainable impact. 